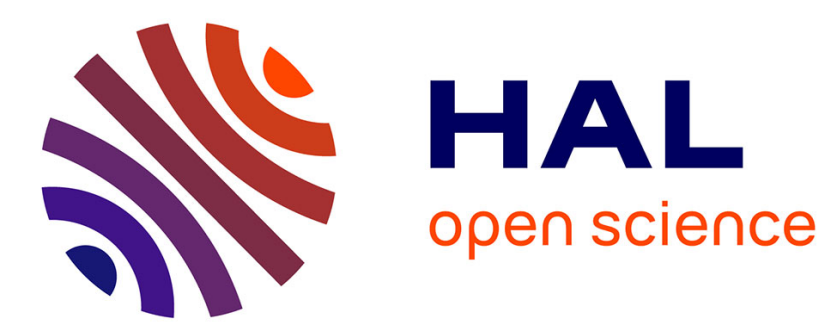

\title{
The ternary diagram of system $\mathrm{Na} 2 \mathrm{O}-\mathrm{CdO}-\mathrm{H} 2 \mathrm{O}$ at room temperature
}

\author{
Yannick Cudennec, Y. Gérault, A. Lecerf
}

\section{To cite this version:}

Yannick Cudennec, Y. Gérault, A. Lecerf. The ternary diagram of system Na2O-CdO-H2O at room temperature. Materials Research Bulletin, 1999, 34 (10-11), pp.1557-1562. 10.1016/S00255408(99)00180-4 . hal-02909013

\section{HAL Id: hal-02909013 \\ https://hal.science/hal-02909013}

Submitted on 29 Jul 2020

HAL is a multi-disciplinary open access archive for the deposit and dissemination of scientific research documents, whether they are published or not. The documents may come from teaching and research institutions in France or abroad, or from public or private research centers.
L'archive ouverte pluridisciplinaire HAL, est destinée au dépôt et à la diffusion de documents scientifiques de niveau recherche, publiés ou non, émanant des établissements d'enseignement et de recherche français ou étrangers, des laboratoires publics ou privés. 


\title{
THE TERNARY DIAGRAM OF SYSTEM $\mathrm{Na}_{2} \mathrm{O}-\mathrm{CdO}-\mathrm{H}_{2} \mathrm{O}$
}

\author{
AT ROOM TEMPERATURE \\ Y. Cudennec, Y. Gérault, and A. Lecerf \\ Laboratoire de Chimie des Matériaux Inorganiques et de Cristallographie, INSA-Rennes, \\ 20 avenue des Buttes de Coësmes, 35043 Rennes Cedex, France
}

(Received December 9, 1998; Accepted December 14, 1998)

\author{
Materials Research Bulletin, Vol. 34, Nos. 10/11, pp. 1557-1562, 1999 \\ https://doi.org/10.1016/S0025-5408(99)00180-4
}

\begin{abstract}
The ternary diagram of system $\mathrm{Na}_{2} \mathrm{O}-\mathrm{CdO}-\mathrm{H}_{2} \mathrm{O}$ at room temperature has been investigated. $\mathrm{CdO}$ and $\mathrm{NaOH}$ solids were used to prepare starting reactional systems. They were slowly hydrated by water vapor. Cadmium and sodium were analyzed in saturated solutions, at each step of the hydration process, using an ICP spectrometer. The solubility curves of $\boldsymbol{\gamma}-\mathrm{Cd}(\mathrm{OH})_{2}$ and $\mathrm{Na}_{2} \mathrm{Cd}(\mathrm{OH})_{4}$ were drawn, and a value of the solubility product of $\gamma-\mathrm{Cd}(\mathrm{OH})_{2}$ is proposed: $\mathrm{Ksp}=4.10^{-14}$ at room temperature.
\end{abstract}

KEYWORDS: A. Inorganic compound, B. Chemical synthesis, D. Phase equilibria.

\section{INTRODUCTION}

Cadmium hydroxide $\mathrm{Cd}(\mathrm{OH}) 2$ is the active anodic material of the nickel-cadmium battery in discharged state. Since 1930, many studies have been carried out on ternary systems:

$\mathrm{M}_{2} \mathrm{O}-\mathrm{CdO}-\mathrm{H}_{2} \mathrm{O}\left(\mathrm{M}^{+}=\mathrm{Li}^{+}, \mathrm{Na}^{+}, \mathrm{K}^{+}\right)$, in which $\mathrm{Cd}(\mathrm{OH})_{2}$ can be prepared [1- 4]. Reports on these studies have often been published without any indication of the allotropic variety $\beta$ or $\gamma$ of the hydroxide. In addition, the reacting systems have been constituted from cadmium salts (nitrate and chloride). Such salts are difficult to eliminate by washing; anionic species introduced can cause equilibria to be perturbed. The most reliable studies on the system $\mathrm{Na}_{2} \mathrm{O}-\mathrm{CdO}-\mathrm{H}_{2} \mathrm{O}$ have been performed by Scholder and co-workers [1,2]. In a paper published in 1941 [1], Scholder and Staufenbiel proposed a diagram at $373 \mathrm{~K}$. Reacting systems were composed of the solid phase $\beta$ $\mathrm{Cd}(\mathrm{OH}) 2$ and a concentrated solution of sodium hydroxide. Two solid phases containing cadmium exist in this diagram: $\mathrm{Cd}(\mathrm{OH})_{2}$ and $\mathrm{Na}_{2} \mathrm{Cd}(\mathrm{OH})_{4}$. Chemical analyses of cadmium in saturated solutions have been performed by a volumetric method using cadmium dipyridinrhodanid complex [5]. The $\beta$ variety of cadmium hydroxide (brucite-type structure) as a starting material does not allow diagram study at room temperature because of its high stability.

More recently, we have shown [6-8] that the use of $\mathrm{LiOH}$ or $\mathrm{KOH}$ gives rise to the $\beta$ variety, whereas $\gamma-\mathrm{Cd}(\mathrm{OH})_{2}$ is obtained with $\mathrm{NaOH}$ after the formation of disodium tetrahydroxocadmiate $\mathrm{Na}_{2} \mathrm{Cd}(\mathrm{OH})_{4}$. We have described a new way to prepare cadmium hydroxide. It consists of a very 
slow hydration, at room temperature, of a mixture containing $\mathrm{CdO}$ and $\mathrm{NaOH}$ solids (similar conditions as these are used in the nickel-cadmium battery).

The aim of this study was the determination, at room temperature, of the solubility curves of $\gamma$ $\mathrm{Cd}(\mathrm{OH})_{2}$ and $\mathrm{Na}_{2} \mathrm{Cd}(\mathrm{OH})_{4}$. A better understanding of the ternary diagram is of great interest in the synthesis of one of the active materials in the $\mathrm{Ni}-\mathrm{Cd}$ battery.

\section{EXPERIMENTAL}

For the study of the ternary diagram of the system $\mathrm{Na}_{2} \mathrm{O}-\mathrm{CdO}-\mathrm{H}_{2} \mathrm{O}$, two starting materials were prepared, using $\mathrm{CdO}$ and $\mathrm{NaOH}$. The first material, denoted by line $\mathbf{r} \mathbf{1}$ in Figure 1, contains 62.2 moles of $\mathrm{NaOH}$ for 1 mole of $\mathrm{CdO}$. The second, denoted by line $\mathbf{r 2}$, contains 12.8 moles of $\mathrm{NaOH}$ for 1 mole of $\mathrm{CdO}$. These homogeneous starting materials are slowly hydrated by water vapor, because of the hygroscopic character of sodium hydroxide, sheltered from carbon dioxide. During the hydration process, their representative points in the diagram follow a straight line from their starting composition towards the figurative point of pure water (Fig. 1). The evolution was controlled by weighting, to determine the amount of water and then the new composition of the system. In order to reach equilibrium, chemical analyses were performed several days after the completion of each hydration step. Analyses of sodium and cadmium were carried out on the saturated solutions, using inductively coupled plasma (ICP) spectrometer. Samples corresponding to the ten systems situated either on $\mathbf{r} \mathbf{1}$ (62.2) for the most concentrated in $\mathrm{Na}_{2} \mathrm{O}$ or on $\mathbf{r} 2$ (12.8) could be analyzed. They were taken out of the saturated solution using a syringe equipped with a $0.2 \mu \mathrm{m}$ filter. The sample weight was approximately $300 \mathrm{mg}$, while the weight of the whole system was about $40 \mathrm{~g}$. Moreover, a visual observation of the reacting system in evolution allowed for confirmation of the limits of crystallization domains of the solid phases.

\section{RESULTS AND DISCUSSION}

The results (in weight percent) of the chemical analyses are reported in Table 1 and shown in Figure 2 , and the ternary diagram is presented in Figure 1. Two solid phases containing cadmium are represented in the diagram (Fig. 1): $\mathrm{Na}_{2} \mathrm{Cd}(\mathrm{OH})_{4}$ and $\boldsymbol{\gamma}-\mathrm{Cd}(\mathrm{OH})_{2}$. Their solubility curves are located very near the baseline $\mathrm{H}_{2} \mathrm{O}-\mathrm{Na}_{2} \mathrm{O}$, due to their weak solubility (Fig. 2). The solution saturated in both $\mathrm{Na}_{2} \mathrm{Cd}(\mathrm{OH})_{4}$ and $\gamma-\mathrm{Cd}(\mathrm{OH})_{2}$. is located at $27.8 \mathrm{wt} \% \mathrm{Na}_{2} \mathrm{O}$ and $7.4 \times 10^{-3} \mathrm{wt} \% \mathrm{CdO}$ (point $\left.\mathrm{N}^{\circ} 4\right)$. This point corresponds to the intersection of the two solubility curves and permits the limits of the domains of pure solids, $\mathrm{Na}_{2} \mathrm{Cd}(\mathrm{OH})_{4}$ and $\gamma-\mathrm{Cd}(\mathrm{OH})_{2}$, to be accurately defined. These domains are denoted by the dotted areas in Figure 1. The part of the domain of $\mathrm{Na}_{2} \mathrm{Cd}(\mathrm{OH})_{4}$ beyond $45 \mathrm{wt} \% \mathrm{Na}_{2} \mathrm{O}$ was not investigated because the systems were too concentrated for solution sampling. Moreover, hydrates of sodium hydroxide can exist in this region.

In Figure 2, the solubility curve located beyond $27.8 \mathrm{wt} \% \mathrm{Na}_{2} \mathrm{O}$ corresponds to the following equilibrium:

$$
\mathrm{Na}_{2} \mathrm{Cd}(\mathrm{OH})_{4}(\mathrm{~s}) \longrightarrow 2 \mathrm{Na}^{+}(\mathrm{aq})+\mathrm{Cd}(\mathrm{OH})_{4}{ }^{2-}(\mathrm{aq})
$$

When the concentration of $\mathrm{Na}^{+}$decreased, an increase of solubilized cadmium was observed (see Fig. 2 ). However, the determination of the solubility product of $\mathrm{Na}_{2} \mathrm{Cd}(\mathrm{OH})_{4}$ was not possible because of the very strong concentration of sodium hydroxide, which is larger than $12 \mathrm{~mol}^{-1}$. 
The second solubility curve, below $27.8 \mathrm{wt} \% \mathrm{Na}_{2} \mathrm{O}$, corresponds to the solubility equilibrium of $\boldsymbol{\gamma}-\mathrm{Cd}(\mathrm{OH})_{2}$ :

$$
\boldsymbol{\gamma}-\mathrm{Cd}(\mathrm{OH})_{2}(\mathrm{~s})+2 \mathrm{OH}^{-}(\mathrm{aq}) \longrightarrow \mathrm{Cd}(\mathrm{OH})_{4}{ }^{2-}(\mathrm{aq})
$$

In this case, when hydroxide ion concentration decreases, solubilized cadmium decreases also (see Fig. 2). When the hydration process is finished, crystals of $\gamma-\mathrm{Cd}(\mathrm{OH})_{2}$ obtained have a needle shape which size can reach several tenths of millimeter (Fig. 3). A powder X-ray diffraction pattern showed that the solid obtained was pure $\gamma-\mathrm{Cd}(\mathrm{OH})_{2}$, without any trace of $\beta-\mathrm{Cd}(\mathrm{OH})_{2}$ (Fig. 4). Therefore, the determination of the solubility product of $\gamma-\mathrm{Cd}(\mathrm{OH})_{2}$ was allowed. After washing the crystals five times with pure water for one month, the concentration of cadmium in the saturated

solution was determined. The solubility product found at room temperature is $\mathrm{Ksp}=4 \times 10^{-14}$. To our knowledge, this is the first time that $\mathrm{Ksp}$ for $\gamma-\mathrm{Cd}(\mathrm{OH})_{2}$ has been determined. It is to be noted that the solubility of $\gamma-\mathrm{Cd}(\mathrm{OH})_{2}$ increases with the different washings. This fact, as it has already been mentioned [4], is due to the formation of the complex $\mathrm{Cd}(\mathrm{OH})^{+}$when concentrations of $\mathrm{NaOH}$ are below $0.5 \mathrm{~mol}^{-1}{ }^{-1}$.

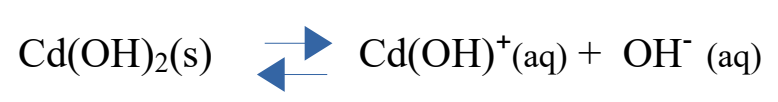

According to the precedent reacting scheme, when the $\mathrm{OH}^{-}$concentration is decreased by washing, the concentration of $\mathrm{Cd}(\mathrm{OH})^{+}$and the solubility of $\mathrm{Cd}(\mathrm{OH})_{2}$ increase. Nevertheless, for highest concentrations, the tetrahydroxocadmiate complex ion $\mathrm{Cd}(\mathrm{OH})_{4}{ }^{2-}$ is formed. The experimental value of Ksp given in several tables for $\mathrm{Cd}(\mathrm{OH})_{2}$ is about $10^{-14}$ and a value calculated from free enthalpies data is $5.3 \times 10^{-15}$ [9], but although the variety is never specified, it is certainly the most stable: $\beta-\mathrm{Cd}(\mathrm{OH}) 2$. If we compare now our results at room temperature with those obtained by Scholder and Staufenbiel [1] at $373 \mathrm{~K}$, we find that the main difference is the obtention of the $\gamma$ $\mathrm{Cd}(\mathrm{OH}) 2$ variety, instead of $\beta-\mathrm{Cd}(\mathrm{OH}) 2$. It is to be noted that solubilities are more important at 373 $\mathrm{K}$, as would naturally be expected; for instance, for the disaturated solution, $\left[\mathrm{Cd}^{2+}\right]=10.8 \mathrm{mmol} . \mathrm{L}^{-1}$ at $373 \mathrm{~K}$ and $\left[\mathrm{Cd}^{2+}\right]=0.80 \mathrm{mmol} . \mathrm{L}^{-1}$ at room temperature.

A recent publication [10] reported the ternary diagram for system $\mathrm{Na}_{2} \mathrm{O}-\mathrm{CuO}-\mathrm{H}_{2} \mathrm{O}$ at room temperature. In this diagram, $\mathrm{CuO}$ (instead of $\mathrm{Cu}(\mathrm{OH})_{2}$ ) and $\mathrm{Na}_{2} \mathrm{Cu}(\mathrm{OH})_{4}$ appear, but the point corresponding to the disaturated solution is nearly $30 \mathrm{wt} \% \mathrm{Na}_{2} \mathrm{O}$. This is similar to the cadmium system. On the other hand, solubilities of copper compounds in the presence of hydroxide ions are more important, while $\mathrm{Ksp}$ of $\mathrm{Cu}(\mathrm{OH})_{2}$ is smaller $\left(10^{-19}\right)$. This means that the complex $\mathrm{Cu}(\mathrm{OH})_{4}{ }^{2-}$ is more stable than the complex $\mathrm{Cd}(\mathrm{OH})_{4}{ }^{2-}$.

\section{CONCLUSION}

This study confirms the results reported in previous publications [6,7]: solubility is more important for $\gamma-\mathrm{Cd}(\mathrm{OH})_{2}$. This means that, under the same conditions, $\gamma$ is less stable than $\beta$ is, as it has been proved with the determination of decomposition enthalpies for $\gamma$ and $\beta$, by DSC. Thus, $\gamma$ transforms progressively into $\beta$, whose grain size may be important if the transformation is slow. This evolution has a harmful effect on the operating cycles of batteries. Consequently, the use of pure $\mathrm{NaOH}$, which gives rise to the $\boldsymbol{\gamma}$ variety, must be prohibited.

\section{ACKNOWLEDGMENTS}

The authors thank Dr. C. Paul for proofreading the English version of this publication. 


\section{REFERENCES}

1. R. Scholder and E. Staufenbiel, Z. Anorg. Allg. Chem. 247, 259 ( 1941).

2. R. Scholder and F. Schwochow, Angew. Chem. Int. Ed. 5, 1047 (1966).

3. R. Bonnaterre and R. Doisneau, M.C. Petit, and J.P. Stervinou, Proceedings of the Eleventh International Power Sources Symposium, Brighton, p. 249 (1978).

4. D.E. Ryan, J.R. Dean, and R.M. Cassidy, Can. J. Chem. 43, 999 (1965).

5. G. Spacu and J. Dick, Z. Anal. Chem. 73, 279 (1928).

6. Y. Cudennec, A. Lecerf, A. Riou, and Y. Gérault, Mater. Res. Bull. 24, 381 (1989).

7. A. Lecerf, A. Riou, Y. Cudennec, and Y. Gérault, Mater. Res. Bull. 23, 1479 (1988).

8. A. Riou, Y. Cudennec, and Y. Gérault, Mater. Res. Bull. 25, 987 (1990).

9. Handbook of Chemistry and Physics, 76th ed., CRC Press, Boca Raton, FL (1996).

10. Y. Cudennec, A. Lecerf, and Y. Gérault, Eur. J. Solid State Inorg. Chem. 32, 1013 (1995).

TABLE 1

Chemical Composition of Saturated Solutions

\begin{tabular}{lcccccccccc}
\hline \multicolumn{1}{c}{ System } & 1 & 2 & 3 & 4 & 5 & 6 & 7 & 8 & 9 & 10 \\
\hline $\mathrm{Na}_{2} \mathrm{O}(\mathrm{wt} \%)$ & 40.2 & 37.5 & 30.1 & 27.8 & 26.0 & 22.9 & 20.0 & 14.9 & 6.8 & 0.064 \\
$\mathrm{NaOH}(\mathrm{wt} \%)$ & 51.9 & 48.4 & 38.9 & 35.9 & 33.6 & 29.6 & 25.8 & 19.2 & 8.8 & 0.083 \\
$\mathrm{Density}(\mathrm{g} / \mathrm{cc})$ & 1.53 & 1.51 & 1.42 & 1.39 & 1.36 & 1.32 & 1.28 & 1.21 & 1.10 & 1.00 \\
$\mathrm{NaOH}(\mathrm{mol} / \mathrm{L})$ & 19.8 & 18.3 & 13.8 & 12.5 & 11.4 & 9.8 & 8.3 & 5.8 & 2.4 & 0.021 \\
$\mathrm{CdO} \times 10^{-3}(\mathrm{wt} \%)$ & 0.23 & 1.00 & 6.00 & 7.40 & 4.50 & 2.40 & 1.50 & 0.78 & 0.27 & 0.12 \\
$\mathrm{Cd}^{2+}(\mathrm{aq}) \times 10^{-5}(\mathrm{~mol} / \mathrm{L})$ & 2.7 & 12 & 66 & 80 & 48 & 25 & 15 & 7.3 & 2.3 & 0.93 \\
\hline
\end{tabular}




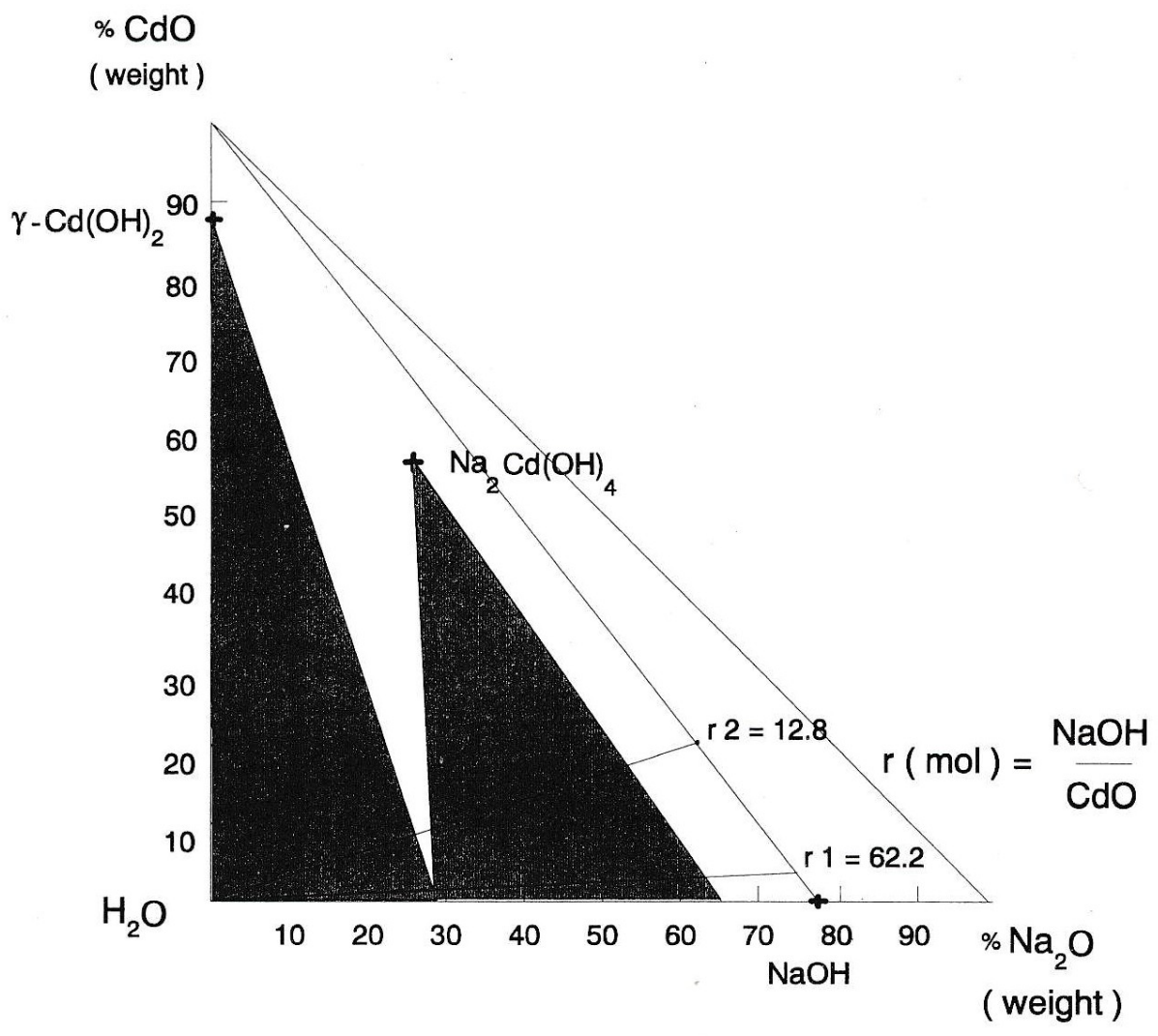

FIG. 1

The ternary diagram of system $\mathrm{Na}_{2} \mathrm{O}-\mathrm{CdO}-\mathrm{H}_{2} \mathrm{O}$ at room temperature. 


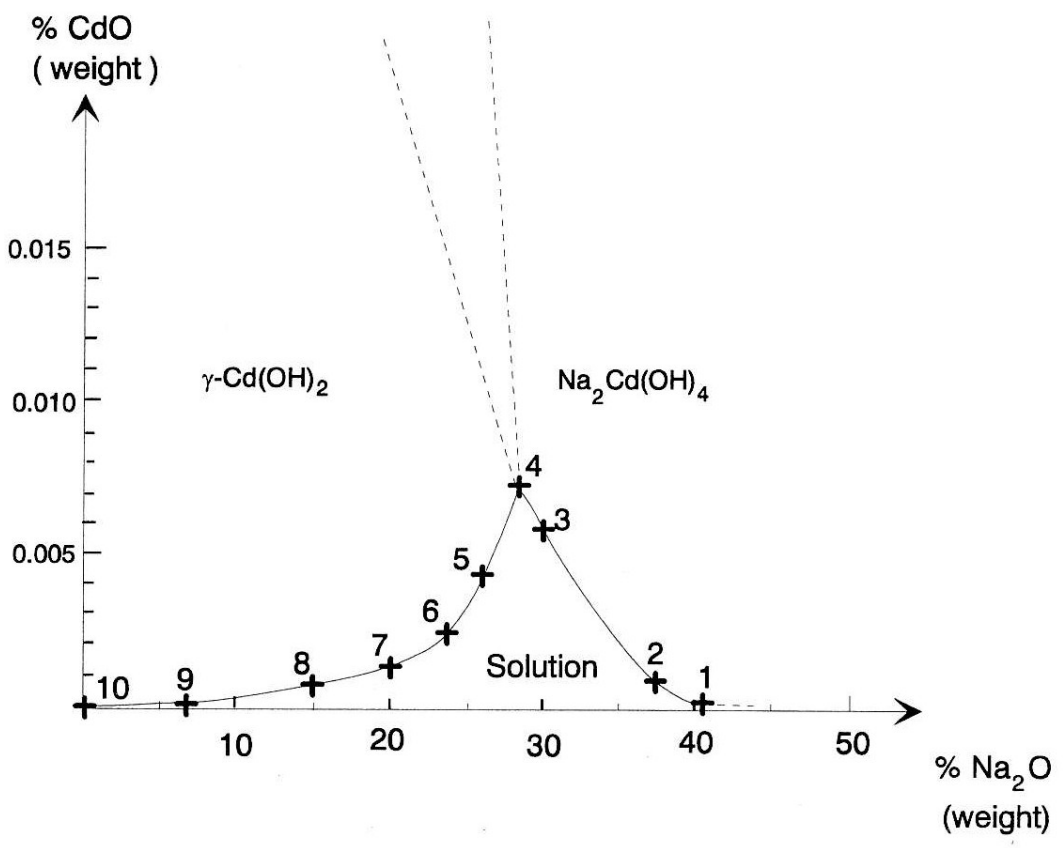

FIG. 2

The ternary diagram of system $\mathrm{Na}_{2} \mathrm{O}-\mathrm{CdO}-\mathrm{H}_{2} \mathrm{O}$ : solubility curves at room temperature.

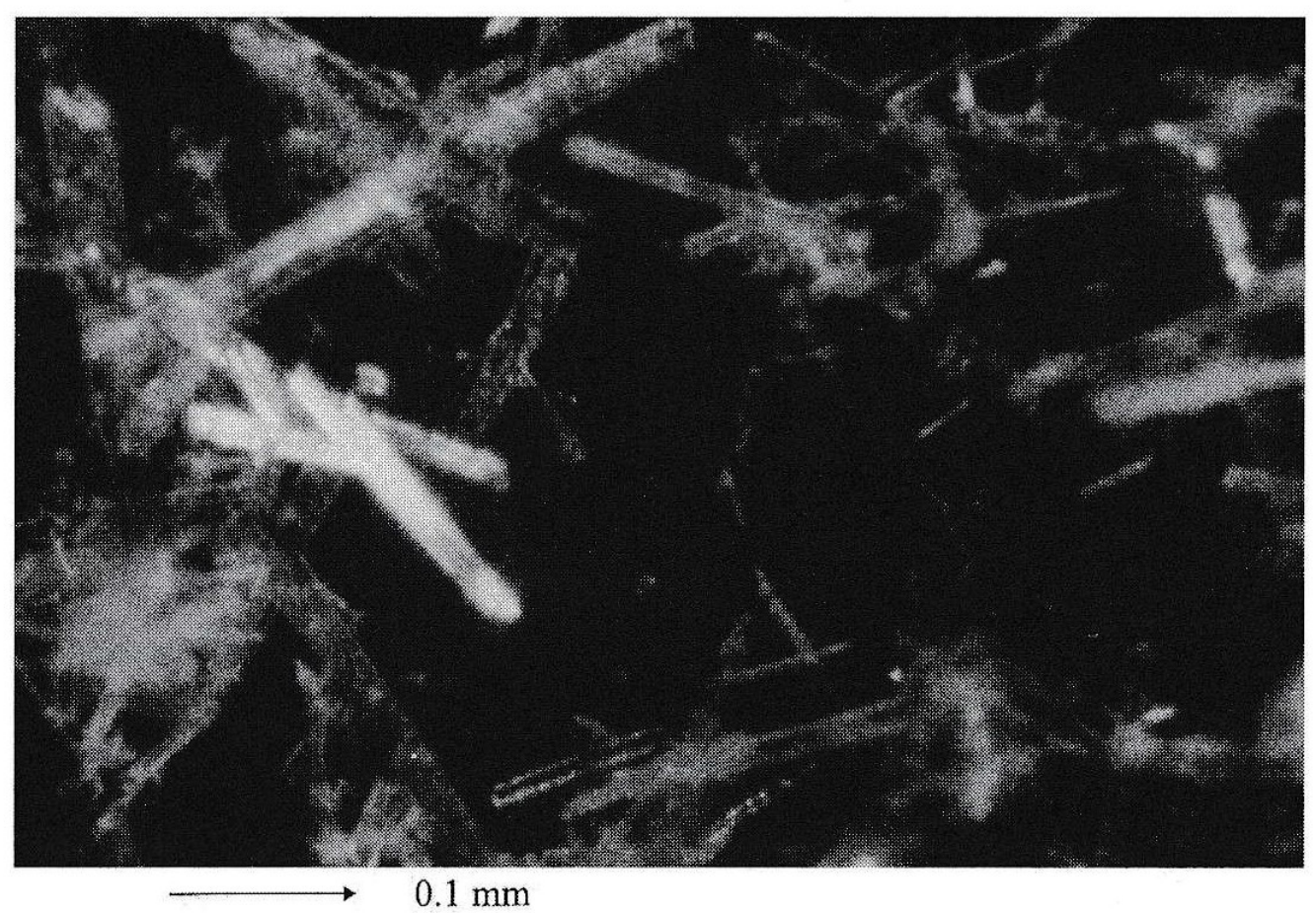

FIG. 3

Optical photograph: $\gamma-\mathrm{Cd}(\mathrm{OH})_{2}$ crystals. 


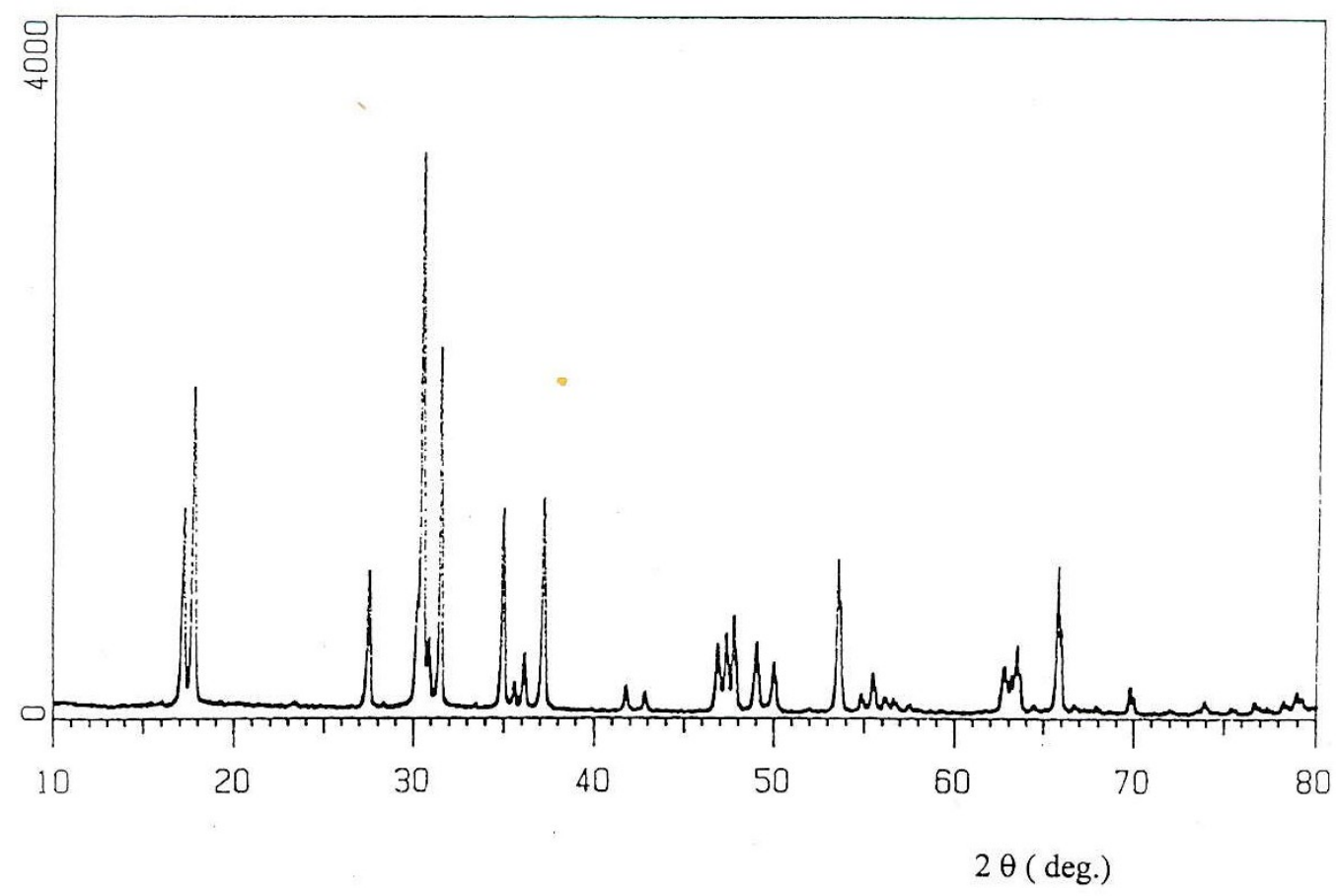

FIG. 4

Powder X-ray diffraction pattern of $\gamma-\mathrm{Cd}(\mathrm{OH})_{2}(\mathrm{Cu} \mathrm{K \alpha})$. 